\title{
Policy Responses to fight COVID-19; the case of Ghana
}

\author{
Joseph Antwi-Boasiako 1 \\ Charles Othniel A. Abbey ${ }^{2}$ \\ Patrick Ogbey ${ }^{3}$ \\ Rita Amponsah Ofori ${ }^{1}$
}

${ }^{1}$ University of Ghana / Department of Public Administration and Health Services Management, Accra - Ghana

${ }^{2}$ University for Development Studies / Faculty of Integrated Development Studies, Tamale - Ghana

${ }^{3} \mathrm{KDI}$ School of Public Policy and Management / Strategic Management, Sejong - South Korea

This paper focuses on the policy responses of Ghana's government with a focus on three areas: health, economic, and social. Ghana had made several policy interventions in these three areas. The study highlighted the adoption of the 3T-approach in health, CAP-20 in economics, and free water and subsidized electricity for citizens as social interventions. The study concludes that the measures undertaken by the Government of Ghana have yielded significant results even though some challenges with delivery mechanisms are identified. The available statistics as of October 25, 2020 on the COVID-19 situation in Ghana further affirm the gains.

Keywords: COVID-19; Africa; Ghana; policy responses.

\section{Respostas políticas para combater a COVID-19; 0 caso de Gana}

Este trabalho se concentra nas respostas políticas do governo de Gana, com foco em três áreas: saúde, econômica e social, onde o país conduziu várias políticas públicas. O estudo destacou a adoção da abordagem 3T na saúde, CAP-20 na economia, e água gratuita e eletricidade subsidiada para os cidadãos como intervenções sociais. O estudo concluiu que as medidas implementadas pelo Governo de Gana produziram resultados significativos, identificando desafios relacionados aos mecanismos de entrega das políticas públicas. As estatísticas disponíveis em 25 de outubro de 2020 sobre a situação da COVID-19 em Gana confirmam os ganhos obtidos.

Palavras-chave: COVID-19; África; Gana; políticas públicas.

\section{Respuestas políticas para combatir la COVID-19: el caso de Ghana}

Este documento se concentra en las respuestas políticas del gobierno de Ghana con un enfoque en tres áreas; salud, económica y social, en las cuales el país condujo varias políticas públicas. El estudio destaca la adopción del enfoque 3T en salud, CAP-20 en economía y agua gratuita y electricidad subsidiada para los ciudadanos como intervenciones sociales. Asimismo, el estudio concluye que las medidas implementadas por el Gobierno de Ghana han arrojado resultados significativos, aunque se identifican algunos desafíos relacionados con los mecanismos de ejecución de las políticas públicas. Las estadísticas disponibles al 25 de octubre de 2020 sobre la situación de la COVID-19 en Ghana confirman los avances logrados.

Palabras clave: COVID-19; África; Ghana; políticas públicas. 


\section{INTRODUCTION}

Dye (2007) has defined public policy as what government chooses to do or not do. Olssen et al. (2004) also define policy as any course of action that relates to selecting goals, defining values, and allocating resources. According to Ward et al. (2016), policy makers devise targets and programmes and put plans into action. As the COVID-19 has been declared as a pandemic by the World Health Organization (WHO), governments around the world are coming up with different policy responses to reduce the impact of this health crisis in their countries.

Due to the dire impact of the pandemic on all facets of governance, governments are responsible for taking swift actions to mitigate the impact. Torjman (2005) explained that, as opposed to proactive policies, a reactive policy is critical to addressing health and environmental decisions. It is explained that with policy responses in times of these crises, potential solutions become formalized through program directives, the creation of special initiatives, making new legislation, and amending existing legislations (Torjman, 2005).

With the novel nature of the COVID-19, different researches are being carried out in various fields of which public administration is no exception. Public administration as an applied field offers more insights on how governments are responding to the pandemic. Hale, Petherick, Phillips and Webster (2020) assert that as governments around the world continue to respond to the COVID-19, "it is imperative to study measures they are taking and also how these measures have been effective or not". Despite being predicted to be hard hit, the African continent has not seen the severe impact of the COVID-19 like other continents. A specific focus on Ghana is also critical to the discourse as Taylor and Berger (2020) reports that when it comes to the coronavirus response, "the World Health Organization is studying some of Ghana's techniques". Through a documentary analysis, the paper, therefore, focuses on the policy responses of Ghana's government with a focus on three areas; health, economic, and social. The rest of the paper focuses on some policy responses by governments around the world, the methodology, an overview of the health system in Ghana, and the discussion on the policy responses by the Ghana government

\section{POLICY RESPONSES TO COVID-19 - SOME EVIDENCE FROM AROUND THE WORLD}

Ward et al. (2016) have argued that policy responses are complex, contextualized and fragmented. They are driven by a range of forces that have health, environmental, economic or social impact (Torjman, 2005). He further explains that for instance, the 2003 SARS crisis in Toronto generated new policies and responses that would not have been introduced in the absence of this crisis. Hale et al. (2020) assert that, globally, the rapid spread of the COVID-19 has created a wide range of responses from governments including travel restrictions, school closures, bans on public gatherings, contact tracing, social welfare provision, improvement in healthcare facilities, stimulus packages for businesses and individuals, among others. These interventions or responses are in place to contain the spread of the virus, manage the economic impact of the virus, and augment the health systems already in place. Hale et al. (2020) have shown in Figure 1: COVID-19 Government Response Stringency Index that governments, since recording cases of COVID-19, adopted different measures including school closures, workplace closures, and travel bans. In the Stringency Index, they measure how strict 
government responses have been. They show that governments adopted more strict measures at the beginning of the pandemic and have since been easing the restrictions as the fatalities reduce.

FIGURE 1 COVID-19: GOVERNMENT RESPONSE STRINGENCY INDEX, OCT 27, 2020

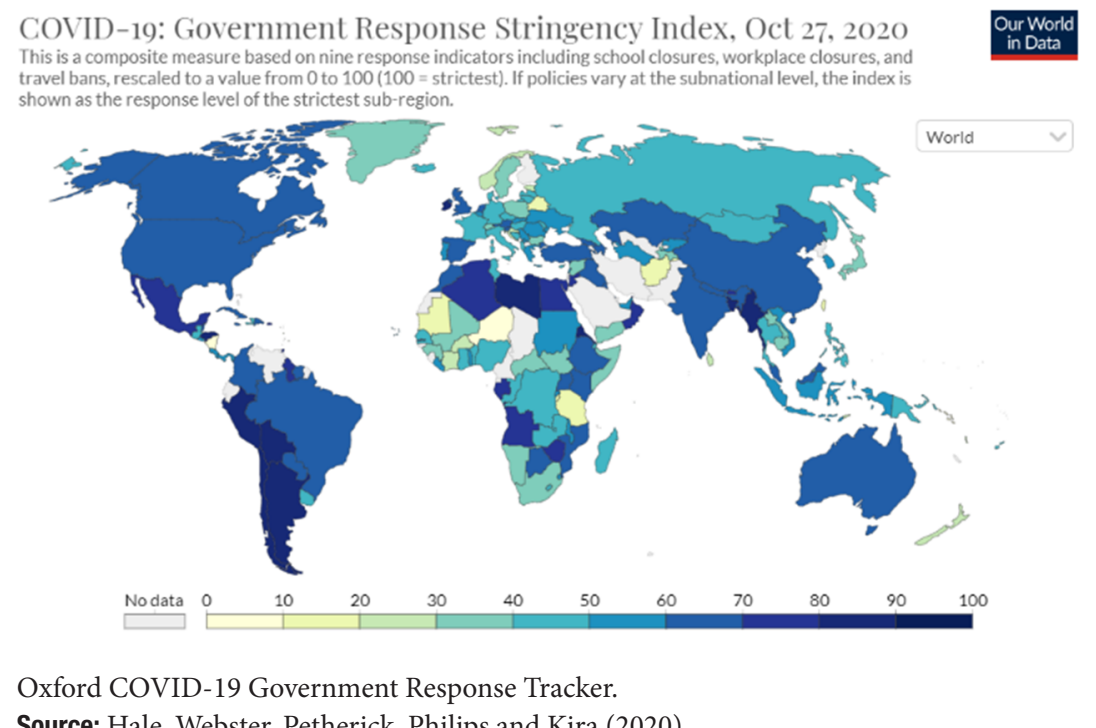

Source: Hale, Webster, Petherick, Philips and Kira (2020).

Regarding health policies, specifically concerning testing policies adopted by governments around the world, Ritchie, Roser, Ortiz-Ospina and Hasell (2020) have grouped countries into four categories. The categories are no testing, testing only for those who have symptoms and key persons, testing for anyone showing any of the COVID-19 symptoms and the open public for testing even available for asymptomatic people. As a global pandemic, almost every country in the world has a testing policy in place. However, the choice of the testing policy has largely depended on the capability of the country to carry tests. WHO (2020) had recommended countries adopt an open testing policies or popularly referred to as mass testing where even asymptomatic patients who could as well spread the virus be tested and isolated. However, with the associated cost of the tests and its availability, many countries especially in Africa largely depended on the focused testing where people who are showing symptoms were the focus of the testing. Countries such as South Korea, Russia, Germany, and Luxembourg are among countries that were conducting mass testing and have tested a larger number of their populations (Broom, 2020; Stewart, 2020). As the cases and fatalities around the world keep dropping, countries around the world have also relaxed their testing policies (Hale et al., 2020).

On the African continent, Hale et al. (2020) report that, countries have adopted one of the above categories as their testing policy as shown in Figure 2. It is shown that a larger percentage of the countries in Africa are focusing on only testing people with symptoms with just a very few adopting the public testing approach. In a report in The Guardian, Kate Dooley, Director for West Africa at the Tony Blair Institute has explained that governments are rationing their use of test kits due to limited supplies (Akinwotu, 2020). She further explained that African countries who have placed orders for 
more test kits are even yet to receive their supplies after months with plausible reasons including demand outstripping supply. As some countries relax most of the restrictions, these countries have made changes to their testing policies for different reasons including health and economic. On health, as many people do not report sick or the mortality rates have fallen worldwide, countries have also relaxed their testing policies, so they do not incur costs.

\section{FIGURE 2 COVID-19 TESTING POLICIES, OCT 27, 2020}

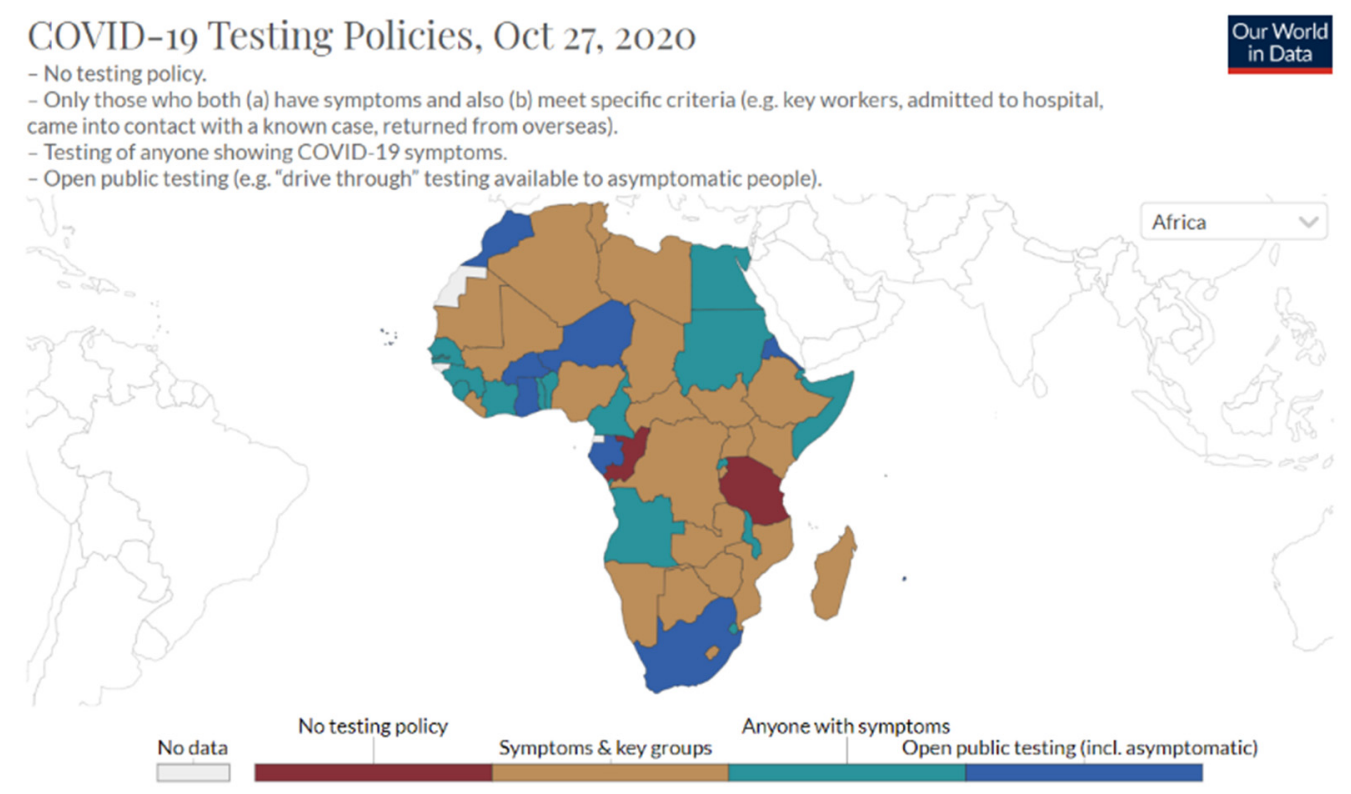

Oxford COVID-19 Government Response Tracker.

Source: Hale et al. (2020).

Ozili and Arun (2020) narrate that the COVID-19 has had a spill-over on various facets of human life including hospitality, travel, sports, health, financial, among other sectors. Undoubtedly the COVID-19 is testing the resilience of individuals, families, businesses, and nations in responding to pandemics. As a policy response, many countries like the United States, United Kingdom, Japan, and Australia are approving large stimulus for sectors and industries to mitigate the effect of the COVID-19 (Duffin, 2020; Ozili \& Arun, 2020). Duffin (2020) reports that among the G-20 countries, Japan had passed the largest fiscal stimulus package that amounts to about 117 trillion Yen (about USD\$ 1.1 trillion). In Africa, several countries have also announced stimulus packages to mitigate the effect of the pandemic. For instance, the South African government in April launched an economic and social stimulus package worth over R500 billion (about USD \$26.3 billion) (Schneidman, McLaren \& Taylor, 2020). Likewise, according to the International Monetary Fund (IMF) (2020), Namibia launched an economic stimulus and relief package worth 8 billion Namibian dollars (about USD $\$ 482$ million) on the $1^{\text {st }}$ of April 2020 to mitigate the impact of COVID-19. 


\section{METHODOLOGY}

The research was conducted using the qualitative document analysis approach. Document analysis is a social research method and an important research tool that is interpreted to give voice and meaning around an assessment topic (Bowen, 2009). This approach according to Wach, Ward and Jacimovic (2013) is mostly used in the field of political science to ensure that policies are analyzed consistently. Scholars have explained that the qualitative document analysis approach is appropriate for analyzing policies (Martuscelli, 2020; Wach et al., 2013). O'Leary (2014) asserts that there are three primary types of documents that can be used in document analysis which are public records, personal documents, and physical evidence. In this study that examines government policies, public records are used. Dye (2007) avers that government policies may either be written or unwritten. In a crisis like COVID-19, governments may make use of unwritten policies in the haste to protect the lives of its citizens as well as mitigating the impact of the pandemic. Likewise, in the case of Ghana, several policies have been declared by the President in his regular public address to the state to update citizens on the "the measures taken against the spread of coronavirus". The study analyzed three of the policies adopted by the government of Ghana to mitigate the pandemic. These policies have shown to be critical policies that also cut across the three important facets of governance in a health crisis; health, economic, and social. The study conducted a content analysis of these policies to understand the policies adopted. The study also made use of secondary sources of data like news reports, COVID-19 situation reports, and data from some selected countries in the African continent to support the analysis.

\subsection{Overview of Ghana and its healthcare system}

Ghana is a multi-party democratic constitutional republic with a unicameral parliament. The head of state is the executive president, who is directly elected for four years for a maximum of two terms by a majority vote of more than $50 \%$. Ghana has operated a four-tier metropolitan and a three-tier municipal and district decentralized local government within the legal framework of the 1992 Constitution and the Local Government Act (Act 462) of 1993 (Bawole, 2016) and the Local Governance Act (936) of 2016 as amended. The objective of the decentralization is clearly stated in Article 240 of the 1992 Constitution that local government and its administration shall be decentralized, and that the functions, powers, responsibilities, and resources should be transferred from the central government to the local governments (metropolitan, municipal, and district assemblies). Ghana's decentralization has not been as effective as described in the legal framework. Several scholars have found some limitations to Ghana's decentralization system. For instance, Yeboah-Assiamah (2016) concluded in his study that various provisions in the legal framework that do not genuinely transfer autonomy and power to local governments in Ghana. This according to him has also translated into the central bureaucracy in the ministries, departments, and agencies where there is the "unwillingness of decentralized departments and agencies to cede power to the local government leadership, refusing full integration" (Yeboah-Assiamah, 2016, p. 694). The verdict out there among practitioners is that Ghana practices 'centralized decentralization'. 
Ghana has a Ministry of Health around which the health system revolves. The major role the Ministry plays is the formulation of policies, coordination and regulation of all stakeholders in the health sector. The deficiency of the local government system can as well be found in how the health structure has been set up in Ghana. Abor, Abekah-Nkrumah and Abor (2008) have reported that administratively, the Ministry of Health has a hierarchical organizational structure from the central headquarters in Accra to the regions, districts, and sub-districts. There exist four main categories of healthcare delivery; the public sector (mainly by the Ghana Health Service and the Christian Health Association of Ghana), the private not-for-profit, private for-profit, and the traditional systems (George, Cashin, Saleh \& Lavado, 2012). After policies are formulated by the Ministry, the Ghana Health Service serves as the implementer of the health policies of the state-run government institutions. Likewise, Abor et al. (2008) report that the Ghana Health Service has a Secretariat that has been decentralized to the district level, however, the Ghana Health Service and Teaching Hospitals Act (1996), Act 525 stipulates that the districts report to the regions and the regions report to the national level.

Ghana's healthcare system is regarded as well-developed, as compared to other countries in sub-Saharan Africa. A mixture of the public and private sectors, it is lopsided towards the public with Government spending making up half of the total health expenditure in Ghana (Cornell Policy Review, 2019). Although substantial progress has been chalked in the area of national frameworks and policies such as the Ghana National Healthcare Quality Strategy (2016), there are documented deficits in the provision of public health infrastructure for greater access by the citizenry as well as healthcare workers to enable the country to improve its doctor-to-patient, nurse-to-patient, and midwife-patient ratios. The Association of Chartered Certified Accountants (2013) reported that in practice local organizations lack autonomy, and the majority of decision making is done centrally, thus responsibility for setting staff establishment levels, appointing clinical and administrative staff, and paying salary costs, for example, rests with the government.

\subsection{The COVID-19 situation in Ghana}

On the $12^{\text {th }}$ March 2020, Ghana recorded its first two cases of the coronavirus (Ghana Health Service (GHS, 2020). In a statement issued by the Ministry of Health, both individuals returned to Ghana from Norway and Turkey. Following the first cases, the country witnessed a slow steady increase also imported in the country. On $21^{\text {st }}$ March 2020, after had recorded 21 cases, the President in a national address placed restriction on travel by ordering the closure of Ghana's sea, land and air borders to human traffic with effective from midnight of $22^{\text {nd }}$ March 2020 (KPMG, 2020). The restrictions on travel and the closure of borders continued until it was reviewed on $1^{\text {st }}$ September 2020. In an address to the nation on $30^{\text {th }}$ August 2020, the President of Ghana announced that air borders were reopening to human traffic from the $1^{\text {st }}$ September 2020. The President further announced that land and sea borders continue to remain closed until further notice. 


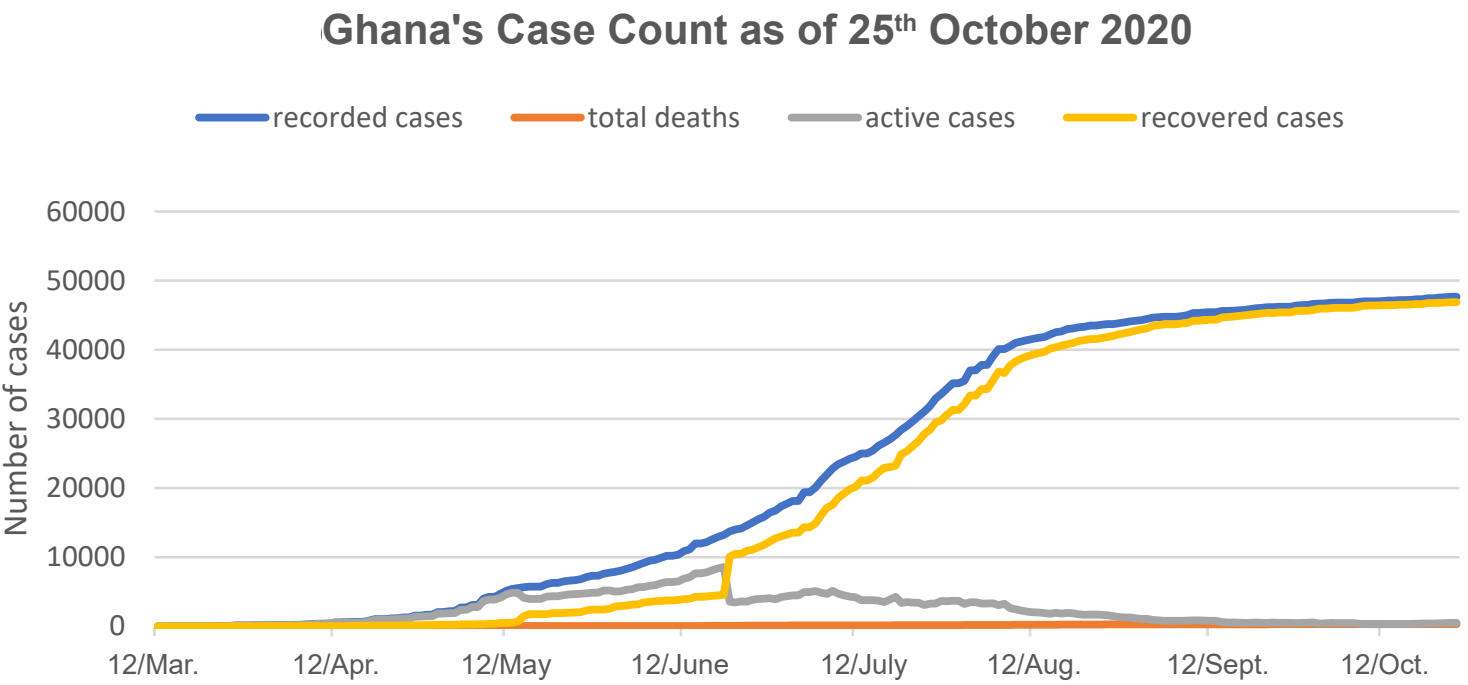

Source: Elaborated by the authors based on data from WorldoMeters as of $25^{\text {th }}$ October 2020 .

Ghana's total case count has increased from the first two cases and stands at 47690 as of $25^{\text {th }}$ October 2020 (See Figure 3). Ghana recorded its highest number with 1513 new cases on 1st August 2020 and according to the GHS of backlogs of samples collected. In every other jurisdiction, Ghana has also seen several recoveries from the coronavirus. On the $26^{\text {th }}$ March 2020, Ghana recorded its first recovery according to the GHS. As of $25^{\text {th }}$ October 2020, recovered cases in Ghana stood more than 46,800 . Unfortunately, 316 persons have succumbed to the virus between the $21^{\text {st }}$ of March when Ghana recorded its first death and until the $25^{\text {th }}$ of October 2020 with active cases standing at 487.

\subsection{Policy responses by the Ghana government}

With the nature of Ghana's government, public policy mainly emanates from the Executive President at the center which is then translated to the regional and local government levels whose heads are appointees of the President for implementation. As a result, acknowledgement of the COVID-19 by the Executive indicates that the government is ready to respond to the crisis. It is a result of this that the President adopted a televised address to the nation to update citizens on the measures put in place by the government as a response to the crisis. In these addresses are where all policies were outlined for various Ministries, Department, and Agencies to follow up with implementation. Critical to the fight has been the earlier admission by the President on the potential of the disease to wreak havoc if proper care is not taken. The early admission is evident in the President's first address on "the enhanced measures taken by the government" on $11^{\text {th }}$ March 2020 when the country had not reported any case of COVID-19. In this address, the President outlined some strategies the country was adopting to even prevent the COVID-19 from entering the country.

Following the first reported cases on $12^{\text {th }}$ March 2020, the government put in place several strategies to mitigate the spread of the coronavirus. Among these responses include limiting and stopping the 
importation of cases, detecting and containing cases, caring for the sick, social and economic responses, domestic capability, and deepen self-reliance (Agyemang-Manu, 2020). For instance, the GHS reported that the first two patients who had tested positive were people who have returned from Norway and Turkey (Osei, 2020). After realizing that subsequent positive cases were also people who were returning from outside Ghana, the government on the $22^{\text {nd }}$ of March 2020 placed a travel restriction by closing all borders (air, land, and sea) to human traffic as a means of limiting and stopping the importation of cases. It is important to emphasize that an Inter-Ministerial Presidential taskforce on COVID-19 was constituted with the President at the head and chairing most of the meetings. This brings to fore the importance attached to the emergency responsiveness and coordinated measures outlined in the public policy responses assessed in this paper. Some policy responses are discussed in the section below with a focus on health, economic, and social used by the government of Ghana to fight the pandemic.

\subsection{Health}

In the area of health, the government's policy responses have come in different forms. The motive has been to ensure that the health sector and healthcare workers can manage the coronavirus situation in Ghana. According to the Health Minister of Ghana, Agyemang-Manu (2020), government interventions in the health sector have included insurance package and tax relief for frontline health workers, tax relief for all health workers for 3 months which have been extended for additional 3 months, setting out isolation facilities for mild cases, strengthen research and developing Ghana Centre for Disease Control and infectious disease centres and last the approach that has helped the country in the fight against the pandemic; the 3-T approach; tracing, testing, and treating. Other health policy responses have come with some controversies. For instance, the package of incentive that was announced by the President on the $5^{\text {th }}$ Address to the Nation on the $5^{\text {th }}$ of April 2020 sparked controversy between the leadership of various health organizations and officials of the Ministry of Health on the definition of who a frontline health worker is in the fight against COVID-19. The frontline health workers were defined by government officials as staff working in the two testing centres, as well as health workers working in designated isolation and treatment centres. This did not go down well with other health workers in the country. This is because for instance, a health worker in a district hospital may be the first point of call for a patient who may be having any of the symptoms of COVID-19. Such a health worker may then isolate such patient and request for a test in the two designated testing centres and be monitoring the patient until the return of the results and then if positive, transfer the patient to the designated COVID-19 isolation and treatment centre. In all of these, such healthcare workers are not classified as frontline workers but rather those they had transferred the patient to isolate and treat were classified as frontline health workers. In a statement issued by the leadership of the Government and Hospital Pharmacy Association of Ghana, they stated that "members are not satisfied with the interpretations being given to the term frontline health worker" (Yeboah, 2020). This is because, for them as pharmacists, they may be issuing drugs from all hospitals in the country until people are transferred to the designated centres and therefore for the interpretations given to frontline workers not to include them is problematic. Some of these policies have on the other hand received great responses from healthcare workers, the citizenry, and the world. The 3T approach being used in Ghana's fight against the coronavirus and the focus of this paper is explained below: 


\subsubsection{The 3T approach - Tracing, Testing, and Treatment}

In addressing public health issues, the $3 \mathrm{~T}$ approach is not novel like the coronavirus. It has been used in different instances to treat different sicknesses. For instance, in 2012, the WHO launched the initiative called the T3: Test, Treat and Track to fight against malaria. The initiative was to provide a framework for malaria-endemic countries to strengthen their fundamental pillars in controlling and eliminating malaria (WHO, 2020). WHO recommended that "every suspected malaria case should be tested, and then every confirmed case should be treated, and the disease tracked through a timely and accurate surveillance system".

In Ghana's COVID-19 response, the President announced in one of his addresses on the $28^{\text {th }}$ March 2020, the policy decision to impose restrictions on movement in selected District Assemblies embark on the $3 \mathrm{~T}$ approach. He stated:

"So, effective 1am on Monday, 30th March, ... I have imposed, ... under the Imposition of Restrictions Act, 2020 (Act 1012), restrictions on the movement of persons...... It will give us the opportunity to try to halt the spread of the virus, and scale-up effectively contact tracing of persons who have come into contact with infected persons, test them for the virus, and, if necessary, quarantine and isolate them for treatment, should they prove to have the virus"

It wasn't until long that Ghana became "the first African Country to lift its coronavirus lockdown" as reported by QuartzAfrica (Asiedu, 2020). In the President's $7^{\text {th }}$ address to the nation, he stated that the decision to lift the restrictions was because of the "ability to undertake aggressive contact tracing of infected persons, the enhancement of our capacity to test, the expansion in the numbers of our treatment and isolation centres". Reuters also reports that the President in addressing a conference about Africa's response to the COVID-19 indicated it is the rigorous programme of 'Test and Trace' that has worked for Ghana to avoid an explosion in cases that could have overwhelmed its health system (Bate, 2020).

\section{FIGURE 4 TESTS CONDUCTED BY AFRICAN COUNTRIES}

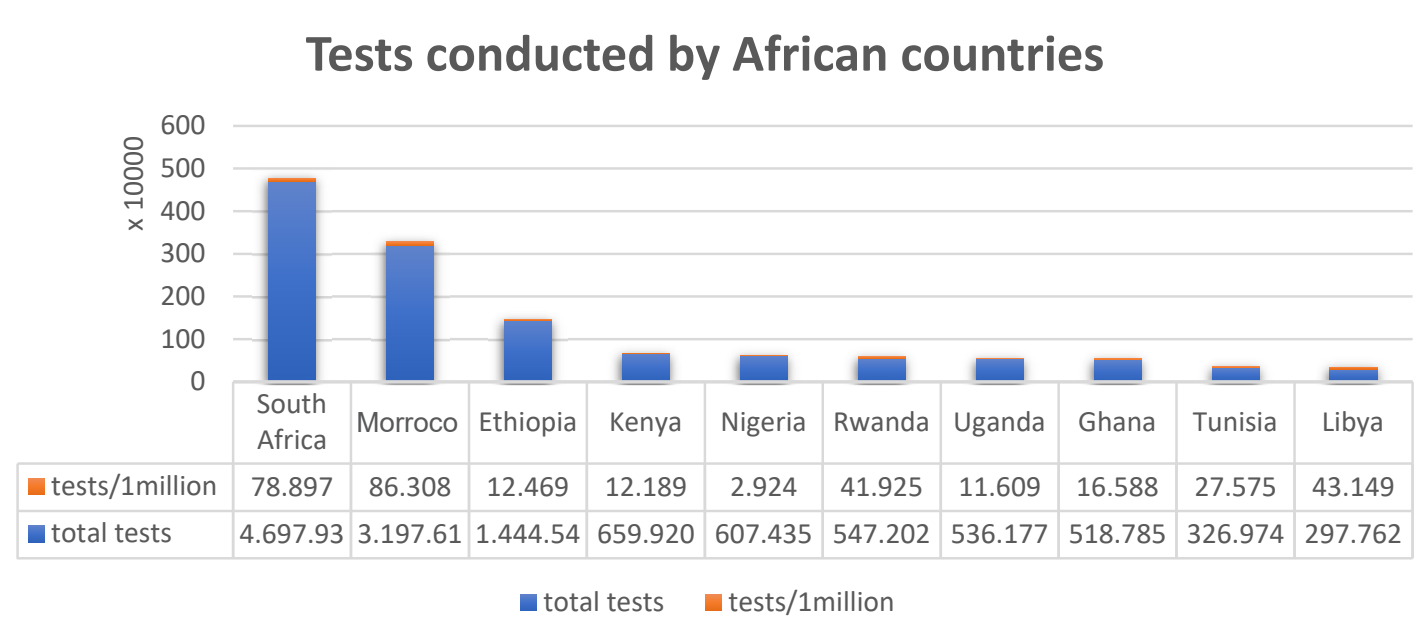

Source: Elaborated by the authors based on data from WorldoMeters as of $25^{\text {th }}$ October 2020. 
Using data from WorldoMeters, we identified the top 10 countries in Africa that have conducted the highest tests for the virus. We identified that as of $31^{\text {st }}$ May, Ghana placed $2^{\text {nd }}$ after South Africa which topped the highest number of tests conducted in Africa. As of $25^{\text {th }}$ August, Ghana dropped to $4^{\text {th }}$ place in testing on the continent. Ghana has further dropped to $8^{\text {th }}$ place on the number of tests conducted by African countries as of $25^{\text {th }}$ October 2020. This drop can be associated with the relaxation of the testing regimes by the health authorities manage the associated testing cost as the government took the burden of all COVID-19 testing costs in Ghana. In July 2020, there seemed to be a relaxation in the 3T approach adopted at the beginning of the COVID-19 fight. The Director-General of the GHS indicated that "henceforth, his outfit would prioritize testing of persons who show symptoms of the coronavirus disease when they report to a health facility". This was to ensure that the country could clear the backlog of samples that had been in the queue for up to a month to get tested. In a press briefing on the $21^{\text {st }}$ July 2020, the Director-General stated that "the numbers I presented today, some of them date back to $22^{\text {nd }}$ June; that's a month ago that will be the policy so that we don't get more backlog so that within 48 hours those who are sick will get their results".

Until the relaxation of the testing policy, Ghana was leading the number of tests performed in the West African region. Again, it is evident in Fig. 4 that, comparing the tests conducted in Ghana as per the million population in the country, Ghana has been doing well in testing a large number of the population. In the treatment of cases of infected patients, Ghana's case compares favourably with other countries in Africa that have the highest number of cases. In Figure 5, despite Ghana being among the ten most infected countries in the African Continent, the number of deaths per number of cases shows that Ghana has been able to manage its mortalities well.

\section{FIGURE 5 TOP 10 CASES IN AFRICA}

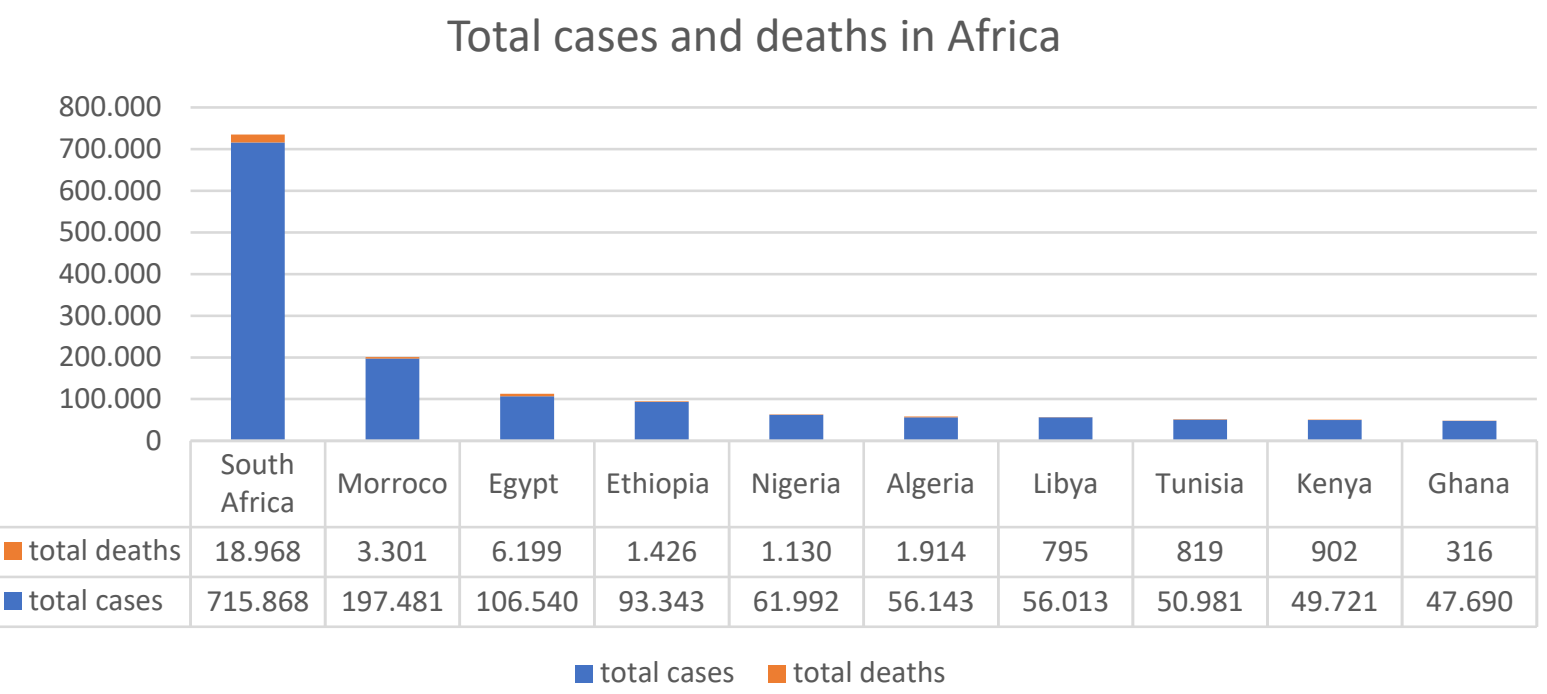

Source: Elaborated by the authors based on data from WorldoMeters as of $25^{\text {th }}$ October 2020 . 
Ghana's effort has also been acknowledged in an article published in the Washington Post titled "When it comes to coronavirus response, superpowers may need to study smaller nations". The article identified Ghana as one of the African countries that are faring better in some ways than countries in Europe and North America. They attributed the success to the extensive testing and stated that the WHO is studying some of Ghana's techniques. Yilmaz and Aydin (2020) have also reported that it is the same $3 \mathrm{~T}$ approach that was used by South Korea and has become a model in the management of the COVID-19. Previously, the use of the enhanced contact tracing, which helped in the testing and isolation for treatment had been helped in the fight against public health issues such as Tuberculosis (Clarke \& Cant, 1996; Esmonde \& Petheram, 1991), Sexually Transmitted Disease (Davidson, 1996; Rothenberg, McElroy, Wilce \& Muth, 2003); and Ebola (Greiner et al., 2015).

The approach though worked well in Ghana's case has, however, been constrained by the issue of resource and infrastructure. At the beginning of the first reported case in Ghana, only two test centres were available to run all tests in the country. The 16 administrative regions with over 30 million population were divided into northern and southern sections and depended on just the two testing centres. News report showed that the Ghana Association of Medical Laboratory Scientists advised the government to resource other centres to test cases rather than depending on the Noguchi Memorial Institute for Medical Research and the Kumasi Centre for Collaborative Research as the only two centres until other centres were configured in some additional facilities. As a result, even though the 3-T approach was in place where people were being traced and tested, in reality, results could take over 72 hours. But for the mandatory quarantine introduced for all persons traced and tested, the return time of the test results could have been a problem.

For the infrastructural deficit that has hindered the country in a pandemic such as this, a new layer of policy response aimed at addressing critical infrastructure shortage to address future challenges is the much-publicised 'Agenda 88' (which has evolved into Agenda 111) - which seeks to construct 100-bed hospitals in at least 88 districts without a district hospital. In addition, the government will provide a new regional hospital in every hospital that does not have such a hospital. Albeit welcomed by many, announced by the President on April 26, 2020 with a start date in July, key questions remain unanswered by the Government: Since the cost of construction was not captured in the 2020 Budget Statement, where would the funds come from? Given that the Minister of Finance read a supplementary budget, critics have alluded to the less than Ghc200million (about USD\$34.3 million) allocation therein as proof of not being a serious initiative of the Government but just a political gimmick and also which districts have been selected to make up the 88 district hospitals to be built?

\subsection{Economy}

Aside from causing severe human suffering and loss of life, COVID-19 has also led to a major economic burden, which is lumbering individuals, businesses as well as governments. The policy responses by the Government of Ghana to mitigate the impact of COVID-19 on the economy can be grouped under fiscal measures and private sector-support (Abbey, 2020). The study focuses on the economic support given to the private sector to mitigate the impact of the virus on business. 


\subsubsection{Coronavirus Alleviation Program (CAP)}

In the President's maiden address, he stated that he had directed the Minister of Finance to send a proposal on the Coronavirus Alleviation Programme (CAP) to Parliament. The evolution of the Government's policy response towards dealing with the immediate effects of COVID-19 was not one without contention. The maiden statement presented by the Minister of Finance to Parliament did not only exclude the mention of targeted measures towards the highly informal nature of the economy (Abbey, 2020) but also got the minority in Parliament casting doubts over the policy intent given their views about the record of Government being fiscally undisciplined as well as unreliable in delivering on other non-COVID-19 related promises. In the $2^{\text {nd }}$ statement to Parliament, the Minister of Finance also indicated that the Coronavirus Alleviation Program Business Support Scheme (CAPBuSS) aligns with objective 4, 'limit the impact of the virus on social and economic life' of the nation's 5-point objective in instituting combat measures against the virus (Ministry of Finance [MoF], 2020). The CAP focuses on protecting against job losses, protecting livelihoods, supporting small businesses, and ensuring the programme is efficiently and sustainably implemented' (MoF, 2020, p. 14). The highly informal nature of the Ghanaian economy, with micro businesses constituting about 85\% (Ministry of Trade and Industry, 2019) and contributing about 70\% to Ghana's GDP (Abor \& Quartey, 2010) were now offered a glimmer of hope of being covered under the new CAPBuSS.

The 1 billion Ghana Cedis (about USD $\$ 174$ million) CAPBuSS, comprising 600million Ghana Cedis (about USD $\$ 104$ million) from Government, with the remaining from the ARB Apex Bank is intended to reach over 230,000 businesses across the 16 administrative regions of Ghana (National Board for Small Scale Industries, 2020). Some questions that have arisen since the launch of the CAP include whether the CAP is good for progressive development? Whether it will help micro-businesses deal with the jeopardy of COVID-19? Answers to these questions have been affirmative. Other questions such as whether the support covers all facets of the national economy remain unanswered as groups such as proprietors of private sector schools - who have responsibility for the remuneration of their teachers and yet have their schools closed-down until 2021- are yet to be answered. Their plight has not escaped public discourse as $44.1 \%$ of employment within the educational sector, a well-affected sector of the economy is provided by the private sector (Ghana Statistical Service, 2015). Drilling further downwards, 33.5\% of teachers employed in the sector out of the 365,168 can be found in private schools (Ghana Education Service, 2018) for which there are growing calls for action by Government since their counterparts in the public schools continue to receive full salaries several months after all schools were shut down.

However, the adequacy of the amount and its proportion to the estimated impact of the COVID-19 on micro-enterprises is still being discussed. What further aggravates the situation for the micro-businesses and the larger intended beneficiaries of the CAPBuSS is the length of time between when the policy intent was signaled and the actualization of the benefits. The fact that it took three (3) months for the first 1,000 applicants to receive in total 1 million Ghana Cedis (about USD\$174,000) as of $24^{\text {th }}$ June 2020 raises several questions especially around the delivery mechanisms and processes that governments must put in place to respond promptly to the effects of large-scale pandemics such as COVID-19. Some medium-scale and small-scale enterprises like the Abbosey Okai Spare Part Dealers at a point called on the government to be swift in the disbursement process as despite, the 
promises they were given on disbursement by July, they were yet to receive any in August (Brown, 2020). What has emerged as an interesting development is the partnership between the public and private sector in setting in motion a delivery mechanism that has the reputable audit firm KPMG as supporting the validation processes of applications and delivery of the financial assistance through mobile money platforms (such as offered by Vodafone) - which is consistent with the overall standing of Ghana as a progressive nation in the use of fintech products to deepen financial inclusion especially in the informal sector. As the pandemic persists, the actual total impact has not been realized. Abbey (2020) reports that the financial loss to master crafts-persons and their apprentices of artisans during 2-weeks of the lockdown in Ghana was around 456 million Ghana Cedis (about USD $\$ 80$ million) which almost consumes the 600million Ghana Cedis (about USD $\$ 104$ million) devoted by the government. As of Thursday, $18^{\text {th }}$ June 2020, more than 450,000 applicants had registered for the programme with 75 percent of the number completing their applications (Donkor, 2020)

The CAP established by the government of Ghana is similar to what has been established in other countries especially in the African continent. The IMF reports that in South Africa, the government is also assisting companies and workers facing distress through the Unemployment Insurance Fund (UIF). A COVID-19 intervention fund of 500 billion Naira (about USD $\$ 1.2$ billion) has also been provided to among other things provide relief and support employers in Nigeria. Other African countries like Zimbabwe putting in place ZWL\$500million (about USD \$1.3 million) to support SMEs, Tanzania supporting the private sector with US\$376 million, and 8 billion Namibian dollars (about USD $\$ 482$ million) as economic stimulus and relief package for Namibia (IMF, 2020).

\subsection{Social}

Apart from the impacts of the COVID-19 on health and the economy, Diwakar (2020) asserts that there are also some social impacts like an increase in poverty and inequality and adverse effects on vulnerable people. Social measures that have been put in place to fight the COVID-19. The President of Ghana in his address on the $15^{\text {th }}$ March 2020 stated that he was banning all public gatherings including conferences and workshops, religious activities, except for private burials that were limited to 25 people attending. These restrictions have been in place until $31^{\text {st }}$ May 2020 where the President in his $10^{\text {th }}$ addresses eased some of the restrictions and allowed for meetings of up to 100 people. As the science of the virus depicts high transmission through human touch and physical interactions, and with the celebration of festivals, funerals, weddings, and mass gatherings not ignoring these, it has been the most prudent to impose a ban. The ban, however deepened the woes of informal business operators such as event organizers and decorators, local performing artists, food vendors, among others. Other social responses that have been put in place include some social protection measures to support the vulnerable in the society such as the distribution of free meals to 'kayayei' - a popular term for the phenomenon of head porters mostly from deprived rural areas of Northern Ghana and working in market places as a carrier of goods. According to the International Labor Organization (2020), the crisis also calls for a social protection system that provides some benefits to meet the needs of the people. Our study focuses on the provision of free water and the electricity subsidy for some Ghanaians as a social protection measure to mitigate the impact of the virus on Ghanaians. 


\subsubsection{Free Water for all Ghanaians and subsidized electricity Water bills}

The WHO has recommended hand washing as one of the most effective ways of reducing the spread of COVID-19. Stoler, Jepson and Wutich (2020) add that if there is inadequate water, it poses additional challenges including cleaning surfaces where COVID-19 would have survived and maintaining clean environments. As frequent washing of hands under running water has become a necessity with most families being home, utility bills especially water and electricity (power) which are a necessity will increase. The policy initiative is to cushion the citizens and reduce the impact of the lockdown that was imposed.

On the free water for all Ghanaians, the President stated in his $5^{\text {th }}$ address that

Government will absorb the water bills for all Ghanaians for the next three months, i.e. April, May, and June. All water tankers, publicly and privately-owned, are also going to be mobilized to ensure the supply of water to all vulnerable communities.

Many Ghanaians went on social media to praise the government's efforts for this initiative. Some scholars have also praised the government's plan to absorb the cost of water (Smiley, Agbemor, Adams $\&$ Tutu, 2020). They described the intervention as a good example of an intervention meant to ease the burden of water access on poor households who may compromise proper hygiene in the time of COVID-19 because of water insecurity (Smiley et al., 2020, p. 2). The big question however remains; how many people will indeed have access to this free water by the government? According to Smiley et al. (2020), a sizable proportion of household are not linked to the national pipeline and have no metered supply and therefore depend on resold water from vendors who sell water door to door using pushcarts, water tankers, and sometimes private wells (Stoler et al., 2020). Unlike the public services, informal water supply systems and their workforce are not obligated to operate these regulated supply chains under emergency conditions (Stoler et al., 2020, p. 2). There have been media reports where citizens called the Ministry of Sanitation and Water Resources hotlines to report that they had not benefitted from the free water service because they did not have direct pipelines and these informal water suppliers were asking them to pay even though the government had indicated they were going to reimburse these private suppliers. The Ghana Water Company Limited has also issued several notices in the print and electronic media requesting private water vendors to contact them for their inclusion in the community water supply reimbursement scheme.

In the $6^{\text {th }}$ address, the President announced an electricity relief package; 3 months free electricity for the vulnerable (life-line customers) and a 50\% subsidy for all other consumers (residential and commercial). Even though the question has also been asked on the electricity relief as to if indeed the targeted vulnerable do even have electricity to benefit from this initiative. Unlike the water supply, the electricity situation did not have such private and informal suppliers. At the end of the three months, the government has announced an extension of the water and electricity packages until the end of 2020. The free water and subsidized electricity as a measure to cushion the social costs of lockdowns and affected livelihoods have been generally welcomed. Some critics however argue that the extension is populist and only for electoral purposes as Ghana goes to the polls in December 2020. Another argument has been that the extension could blow government expenditure out of gear

Brazilian JOURnal OF Public administration ｜ Rio de Janeiro 55(1): 122-139, Jan. - Feb. 2021 
especially in a time where the government is already spending a lot to protect lives against COVID-19. Some section also believes that citizens would see increasing tariffs for these items in 2021 after the current government has won the election- akin to a situation of robbing Peter to pay Paul. The case of Ghana compares favourably with some other African countries who also have in place subsidized social tariffs. The IMF reports that in Togo, the government is subsidizing water and electricity tariffs worth over USD\$3 million. Countries like Uganda, Burkina Faso, and Senegal are also supporting their citizens with subsidies on social tariffs like water and electricity.

\section{CONCLUSION}

The Ghana government has intervened in most of the facets of the human lives affected by the COVID-19. Key among the responses include the 3T-approach, the CAP-20, and the supply of free water, and subsidized electricity for the citizens. The overall policy response within the economy targeting the private sector has also brought to the fore the critique of the conventional capitalist economic theory of minimal (if not completely exclusionary), Governmental intervention in the market economy with governments finding solace in redistribution and welfare policies. The global reports on the number of persons who have sunk further into extreme poverty and thereby eroding the gains of the past decade towards the SDG 1 have also highlighted the need for pragmatic policy responses to pandemics that are not steeped in uncompromising stance towards chosen economic paradigms of nation-states. In imposing total lockdowns in major economic centres of Ghana (Greater Accra, Kasoa, and Greater Kumasi) as well as placing bans on social gatherings with executive instruments regularly amended, the nexus between the social and economic spheres was amplified by the stark reality of livelihoods being at stake. It is without a doubt that the harsh effects on livelihoods contributed to policy responses of the provision of free water supply and subsidized electricity to cushion the lower income-earners from the socio-economic shocks of the crises. The policy responses of the Ghanaian government have so far been positive and continue to contribute greatly to mitigating the impact of COVID-19 on the citizens.

For now, as it is commonly said that 'the end justifies the means', does the $25^{\text {th }}$ October 2020 statistics of fewer than 316 deaths from total cases of 47690 , with recoveries of 46,887 justify the policy responses implemented by the Government of Ghana? Can one further say with certainty that despite the second wave being experienced in Europe and other places, the policy responses by Ghana thus far make the country immune to a similar fate? It is our considered view that the measures implemented by the Government of Ghana which have yielded the present results should be sustained and enhanced whilst ensuring that the broad range of social protection measures instituted are well executed.

The Ghanaian case provides a good example for other African countries and the world at large. As the crisis still lingers and governments continue to make policies to mitigate the impact of the pandemic, future studies can continue to review policies by various governments around the world even as restrictions are eased. 


\section{REFERENCES}

Abbey, C. O. (2020). CAP-20 for COVID-19: The Case of Vulnerable Businesses in Ghana. Retrieved from https://www.myjoyonline.com/opinion/cap20-for-covid-19-the-case-of-vulnerable-businessesin-ghana/

Abor, A. P., Abekah-Nkrumah, G., \& Abor, J. (2008). An examination of hospital governance in Ghana, Leadership in Health Services, 21(1), 47-60. Retrieved from https://doi.org/10.1108/17511870810845905

Abor, J., \& Quartey, P. (2010). Issues in SME development in Ghana and South Africa. International research journal of finance and economics, 39(6), 215-228.

Agyeman-Manu, K. (2020). Covid-19 response; Ghana's Experience. Retrieved from https://apps. who.int/gb/COVID-19/pdf_files/07_05/Ghana.pdf

Akinwotu, E. (2020). Experts sound alarm over lack of Covid-19 test kits in Africa. Retrieved from https:// www.theguardian.com/global-development/2020/ may/26/africa-concerned-over-lack-of-coronavirustesting-kits

Bate, F. (2020). Test and trace has worked for us, Ghana's president say. Retrieved from https:// www.reuters.com/article/us-health-coronavirusghana/test-and-trace-has-worked-for-us-ghanaspresident-says-idUSKBN22B2OE

Bawole, J. N. (2017). Pro-poor decentralization in Ghana: Exploring the facilitators and the limitations. Administrative Theory \& Praxis, 39(2), 122-139.

Bowen, G. A. (2009). Document analysis as a qualitative research method. Qualitative Research Journal, 9(2), 27-40. Retrieved from https://doi. org/10.3316/QRJ0902027

Broom, D. (2020). These are the OECD countries testing most for COVID-19. Retrieved from https:// www.weforum.org/agenda/2020/04/these-are-theoecd-countries-testing-most-for-covid-19/

Brown, N. (2020). Abbosey Okai Spare Part Dealers call for swift disbursement of stimulus package. Retrieved from https://www.myjoyonline.com/ business/economy/abbosey-okai-spare-partdealers-call-for-swift-disbursement-of-stimuluspackage/
Clark, J. E., \& Cant, A. J. (1996). Lesson of the Week: Pitfalls in contact tracing and early diagnosis of childhood tuberculosis. BMJ, 313(7051), 221-222.

Cornell Policy Review. (2019). Better Care, Better Health: Optimizing Healthcare Provision in Ghana. Retrieved from http://www.cornellpolicyreview. com/healthcare-in-ghana/

Davidson, R. (1996). 'Searching for Mary, Glasgow': Contact Tracing for Sexually Transmitted Diseases in Twentieth-Century Scotland. Social history of medicine, 9(2), 195-214.

Donkor, J. (2020, June 25). NBSSI Disburses First Ghc1million to 1,000 CAPBuSS Applicants. Ghanaian Times. Retrieved from https://www. ghanaiantimes.com.gh/nbssi-disburses-firstgh\%C2\%A2-1m-to-1000-cap-buss-applicants/

Esmonde, T. F. G., \& Petheram, I. S. (1991). Audit of tuberculosis contact tracing procedures in south Gwent. Respiratory medicine, 85(5), 421-424.

George, S., Cashin, C., Saleh, K., \& Lavado, R. (2012). Health financing in Ghana. Washington, DC: The World Bank

Ghana Education Service. (2018). Education Management Information System (EMIS) Data for 2017/2018 Academic Year. Accra, Ghana: Author.

Ghana Health Service. (2020). Situation update, Covid-19 outbreak in Ghana as at 7 May 2020. Acra, Ghana: Author. Retrieved from https:// ghanahealthservice.org/covid19/archive.php

Ghana News Agency. (2020, May 08). Ghana records 921 new COVID-19 cases. Retrieved from https:// www.gna.org.gh/1.18262013

Ghana Statistical Service. (2015). Integrated Business Establishment Survey. Retrieved from https://statsghana.gov.gh/gssmain/fileUpload/ pressrelease/SUMMARY\%20REPORT_FINAL_ FINAL_24-5-16.pdf

Greiner, A. L., Angelo, K. M., McCollum, A. M., Mirkovic, K., Arthur, R. ... Angulo, F. J. (2015, December). Addressing contact tracing challenges-critical to halting Ebola virus disease transmission. International Journal of Infectious Diseases, 41, 53-55. 
Hale, T., Petherick, A., Phillips, T., \& Webster, S. (2020). Variation in government responses to COVID-19 (Working Paper, 31). Oxford, UK: Blavatnik School of Government, University of Oxford. Retrieved from www.bsg.ox.ac.uk/ covidtracker

Keener, S., \& Banerjee, S. G. (2005, December). Ghana: Poverty and Social Impact Analysis of Electricity Tariffs (ESMAP Technical Paper 088). Washington, DC: Energy Sector Management Assistance Program. Retrieved from https://www.esmap.org/sites/esmap. org/files/08805GhanaPSIKeenerForWeb.pdf

KPMG. (2020, March 23). Ghana - COVID-19Related Travel Restrictions and Safety. Retrieved from https:/home.kpmg/xx/en/home/insights/2020/03/ flash-alert-2020-094.html

Martuscelli, P. N. (2020). How are refugees affected by Brazilian responses to COVID-19?. Revista de Administração Pública, 54(5), 1446-1457. Retrieved from http://bibliotecadigital.fgv.br/ojs/index.php/ rap/article/view/82220/pdf_401

Ministry of Finance. (2020). Statement to Parliament on the Economic Impact of the COVID-19 Pandemic on the Economy of Ghana. Retrieved from https:// www.mofep.gov.gh/sites/default/files/news/MoFStatement-to-Parliament_20200330.pdf

Ministry of Trade and Industry. (2019, January). The National Micro, Small and Medium Enterprise Policy of Ghana. Accra, Ghana: Author.

National Board for Small Scale Industries. (2020). CAP BuSS. Retrieved from https://nbssi.gov.gh/ capsupport/about/

O'Leary, Z. (2014). The essential guide to doing your research project (2nd ed.). Thousand Oaks, CA: SAGE Publications.

Osei, F. (2020). Norwegian diplomat, Ghanaian from Turkey confirmed as coronavirus carriers to Ghana. Retrieved from https://www.myjoyonline. com/news/national/norwegian-diplomat-ghanaianfrom-turkey-confirmed-as-coronavirus-carriersto-ghana/

President of Ghana. (2020a, March 28). President Akufo-Addo Addresses Nation on Updates to Ghana's Enhanced Response to the Coronavirus Pandemic. Retrieved from http://presidency.gov.gh/index. $\mathrm{php} /$ briefing-room/speeches/1546-president-akufo- addo-addresses-nation-on-updates-to-ghana-senhanced-response-to-the-coronavirus-pandemic

President of Ghana. (2020b, April 05). President Akufo-Addo Address to the Nation by on Updates to Ghana's Enhanced Response to the Coronavirus Pandemic. Retrieved from http:// www.presidency.gov.gh/index.php/briefing-room/ speeches/1555-address-to-the-nation-by-presidentakufo-addo-on-updates-to-ghana-s-enhancedresponse-to-the-coronavirus-pandemic

Ritchie, H., Roser, M., Ortiz-Ospina, E., \& Hasell, J. (2020). Policy Responses to the Coronavirus Pandemic. Retrieved from https://ourworldindata. org/policy-responses-covid

Rothenberg, R. B., McElroy, P. D., Wilce, M. A., \& Muth, S. Q. (2003). Contact tracing: comparing the approaches for sexually transmitted diseases and tuberculosis. The International Journal of Tuberculosis and Lung Disease, 7(12), S342-S348.

Smiley, S. L., Agbemor, B. D., Adams, E. A., \& Tutu, R. (2020). COVID-19 and water access in Sub-Saharan Africa: Ghana's free water directive may not benefit water insecure households. African Geographical Review, 39(4), 324-344. Retrieved from https://doi.org/10.1080/19376812.2020.1810083

Stewart, C. (2020). Coronavirus (COVID-19) tests performed in Europe as of May 27, 2020, by country. Retrieved from https://www.statista.com/ statistics/1109066/coronavirus-testing-in-europeby-country/

Stoler, J., Jepson, W. E., \& Wutich, A. (2020). Beyond handwashing: Water insecurity undermines COVID-19 response in developing areas. Journal of Global Health, 10(1), 010355. Retrieved from https:// doi.org/10.7189/jogh.10.010355

Taylor, A., \& Berger, M. (2020). When it comes to coronavirus response, superpowers may need to study smaller nations. Retrieved from https://www. washingtonpost.com/world/2020/05/16/when-itcomes-coronavirus-response-superpowers-mayneed-study-smaller-nations/

The Association of Chartered Certified Accountants. (2013). Key Health Challenges in Ghana. Accra, Ghana: Author.

Torjman S. (2005). "What is Policy?" Ottawa: Caledon Institute of Social Policy. Retrieved from http://www.caledoninst.org/ 
Wach, E., Ward, R., \& Jacimovic, R. (2013). Learning about Qualitative Document Analysis (IDS Practice Paper In Brief;13). Brighton, UK: Institute of Development Studies. Retrieved from https://www. ids.ac.uk/publications/learning-about-qualitativedocument-analysis/

World Health Organization. (2012). T3: Test Treat and Track. Retrieved from https://www.who.int/ malaria/areas/test_treat_track/en/

Yeboah, I. (2020). Define "frontline health workers" now or...'doom' - GHOSPA. Retrieved from https:// www.graphic.com.gh/news/general-news/definefrontline-health-workers-now-or-ghospa.html

Yeboah-Assiamah, E. (2016). Power to the people! How far has the power gone to the people? A qualitative assessment of decentralization practice in Ghana. Journal of Asian and African studies, 51(6), 683-699.

Yilmaz, M. S. \& Aydin N. (2020). 3 T key to South Korea's success in COVID-19 fight. Retrieved from https://www.aa.com.tr/en/asia-pacific/3t-key-tosouth-koreas-success-in-covid-19-fight/1850084

\section{Joseph Antwi-Boasiako}

https://orcid.org/0000-0002-0460-8852

M.Phil. Public Administration, Department of Public Administration and Health Services Management, University of Ghana. E-mail: joelisk1@hotmail.com; jantwi-boasiako002@st.ug.edu.gh

\section{Charles Othniel Abbey}

Ph.D. Candidate in Social Administration, Faculty of Integrated Development Studies, University for Development Studies, Ghana; Guest Lecturer at Valley View University Graduate School.

E-mail: chals.abbey@gmail.com

\section{Patrick Ogbey}

https://orcid.org/0000-0002-2910-0780

Master in Public Management (Strategic Management), KDI School of Public Policy and Management, South Korea. E-mail: pogbey@kdis.ac.kr

\section{Rita Amponsah Ofori}

B.Sc. Health Services Management, Department of Public Administration and Health Services Management, University of Ghana; Content Lead at Studentshubgh. E-mail: phoenix22rita@gmail.com 